\title{
Adam Siwiec, Nazwy wlasne obiektów handlowo- -ustugowych w przestrzeni miasta, Wydawnictwo Uniwersytetu Marii Curie-Skłodowskiej, Lublin 2012, ss. 231
}

Książka Adama Siwca pt. Nazwy własne obiektów handlowo-ustugowych w przestrzeni miasta wpisuje się w nurt współczesnych zainteresowań onomastyki słowiańskiej, która koncentruje się obecnie na chrematonimach. Zauważa to sam autor, który pisze, że nazwy osobowe i geograficzne usuwają się na dalszy plan, natomiast ,rozwijana jest koncepcja chrematonimii jako zasobu nazw obiektów występujących w różnych układach współczesnej kultury, której uczestnikiem jest dana społeczność językowa, oraz chrematonomastyki jako dziedziny badań i subdyscypliny onomastycznej" [Siwiec 2012: 8].

Przedmiot badań w recenzowanej książce stanowią nazwy sklepów i firm, tj. obiektów i instytucji występujących w sferze działalności gospodarczej, ściśle łączącej się z procesem wymiany dóbr i usług, z pośredniczeniem w dystrybucji różnych towarów dostępnych na rynku, czyli z handlem, ale też z szerzej rozumianą ofertą usługową [Siwiec 2012: 8-9]. Problematyka podjęta przez badacza jest istotna, ponieważ dotyczy nazewnictwa związanego z rozwojem cywilizacyjnym, onimii zmieniającej się wraz z pojawianiem się coraz to nowszych obiektów i wytworów.

Autor zwraca uwagę na specyfikę analizy obiektów handlowo-usługowych, których postać językowa oraz metoda opisu zależą od czterech ważnych czynników:

a) najistotniejszych cech charakterystycznych dla danej klasy obiektów, motywacji i kontekstów społeczno-kulturowych procesów nominacji,

b) umiejscowienia w określonej przestrzeni fizycznej,

c) liczebności obiektów,

d) okresu trwania obiektów w rzeczywistości pozajęzykowej. 
Badania nad wybranymi obiektami prowadzone były w latach 1999-2011 w różnych ośrodkach miejskich: Lublinie, Poznaniu, Warszawie, Krakowie, Toruniu i Bydgoszczy. Autor przeprowadzał obserwacje, podczas których spisywał nazwy z szyldów i tablic reklamowych (ilustracje niektórych z nich wzbogacają książkę), ponieważ słusznie zauważył, że w taki sposób „najpełniej ujawnia się ich specyfika jako nazw zjawisk semiofizycznych" [Siwiec 2012: 17]. Ze względu na to, że celem monografii było opracowanie dużej liczby nazw, podstawowe źródło badań stanowiły indeksy branżowe z danymi teleadresowymi przedsiębiorstw: wydania papierowe i internetowe bazy danych „Panoramy Firm” oraz „Polskich Książek Telefonicznych”. Do celów porównawczych wykorzystane zostały elektronicznie dostępne dane dotyczące badanego typu obiektów w innych krajach.

Praca składa się z dwóch części: teoretycznej (rozdziały 1-5) oraz materiałowej (rozdziały 6-12). W pierwszej części autor podejmuje problem klasyfikacji onomastycznej, trudności w jednoznacznym definiowaniu terminów związanych z tą dziedziną. Analizuje także onimy w kontekście zjawisk nominacji i komunikacji oraz nazwy sklepów i firm jako przedmiot badań systemowo-uzualnych.

W pierwszym rozdziale części teoretycznej, zatytułowanym Uwagi o teoretycznych aspektach badań onomastycznych, badacz dostrzega konieczność teoretycznego uporządkowania gromadzonego materiału. Zwraca uwagę na rolę rozważań ogólnoteoretycznych, które - jego zdaniem - przyczyniają się do tego, że onomastyka jest samodzielną dyscypliną naukową w ramach lingwistyki. Ich istotę podkreśla sam, poświęcając bardzo dużo miejsca kwestiom metodologiczno-terminologicznym. Teoria pełni jego zdaniem istotne funkcje: opisową, objaśniającą, organizującą oraz metodologiczną [Siwiec 2012: 28]. Podczas każdych badań, w związku z przyrostem treści empirycznych, konieczne są uporządkowanie teorii i redefinicja niektórych pojęć onomastycznych.

Kolejny rozdział pt. Problemy klasyfikacji onomastycznej. Ustalenia terminologiczne jest rozwinięciem poruszonego wcześniej tematu uporządkowania gromadzonego materiału. Zostały w nim zawarte zagadnienia dotyczące klasyfikacji nazw w sferze handlu i usług. Zgodnie z przyjętym założeniem o zmienności teorii lingwistycznych Adam Siwiec podejmuje rozważania nad przynależnością badanych przez niego obiektów do klasy chrematonimów. Badacz uwzględnia w nich różne koncepcje - oprócz polskiej m.in. wschodniosłowiańską. Wskazuje problemy związane z wielością stosowanych terminów, np. instytucjonim, ergonim, ktematonim, ergourbonim, logonim, stworzonych do klasyfikowania różnego rodzaju nazw instytucjonalnych i handlowych 
[Siwiec 2012: 36-37]. Autor słusznie podkreśla konieczność wyjścia poza klasyczne rozumienie pojęć i w swych badaniach bierze pod uwagę także nazwy uznawane przez niego za ambimodalne, czyli takie, które łączą nazywanie pospolite z własnym. Nieodzowność takiej decyzji argumentuje, podając przykład ilustrujący, że w niektórych sytuacjach komunikacyjnych rozróżnianie onimu od apelatiwum nie jest niezbędne, ponieważ osoba słuchająca wypowiedzi: Wczoraj robiłem zakupy $w$ domu obuwia, nie zastanawia się nad tym, czy chodzi tu o obiekt, który nosi nazwę Dom Obuwia, czy jest to obiekt nazywany domem obuwia.

Następny rozdział zatytułowany Jeszcze o terminach w teorii onomastycznej $i$ ich roli w klasyfikacji i analizie nazw handlowych wydaje się niepotrzebnie wydzielony z poprzedniego. Takie rozgraniczenie może być jednak zasadne. Ta część pracy jest wprawdzie uzupełnieniem zapisu zawartego w poprzednim fragmencie, ale punktem wyjścia jest tu terminologia i wynikające z niej konsekwencje dla klasyfikacji i analiz onomastycznych, które mają służyć merytorycznemu opisowi odpowiedniemu do onimicznych właściwości badanych nazw [Siwiec 2012: 45].

Dalszy rozdział pt. Nazwy własne w kontekście nominacji i komunikacji obejmuje rozważania na temat różnych aspektów nominacji. Autor zwraca w nim uwagę na to, że nie należy rozdzielać zjawisk nominacji i komunikacji, ponieważ aktowi nominacji zawsze towarzyszy sytuacja komunikacyjna.

W drugiej części monografii badacz wiąże analizę zebranego materiału z rozważaniami teoretycznymi. W pierwszym rozdziale zatytułowanym Nazwy sklepów i firm jako przedmiot badań systemowo-uzualnych (Działanie konwencji) zgłębiony zostaje problem pogodzenia jednostkowości nazw (np. nazwa zakładu krawieckiego: Apala Sapna, oznaczająca w języku indiańskim 'piękny sen' [Siwiec 2012: 71]) z ich seryjnością (np. seria tematyczna sklepów z artykułami dla dzieci: Bąbel, Brzdac, Bobo [Siwiec 2012: 78]). Walorem tego rozdziału jest niewątpliwie przedstawienie części danych za pomocą systematyzujących materiał tabel.

Dokładniejszą analizę propriów zebranych w miastach: Krakowie, Lublinie, Warszawie, Poznaniu, Bydgoszczy i Toruniu rozpoczyna autor w rozdziale pt. Nazwy handlowe wobec zmian rzeczywistości społecznej (u progu XXI wieku) - w perspektywie miasta jako tekstu kultury. Podkreśla w nim zależność pomiędzy nazwami sklepów i firm a pewnymi faktami i procesami kulturowymi. Ilustruje to licznymi przykładami. W czasach socjalizmu nominacja zależała od władz państwowych, które zalecały nazwy: Naprzód, Jedność, Równość, Wolność. Rozwój telewizji spowodował powstanie nazw odwołujących się do bohaterów tego medium, np. Alexis (z serialu Dynastia), Król Lew, 
Blue Velvet. Tendencję i modę na język angielski odzwierciedlają nazwy: Job Center, Take It, Open Point, New Idea.

W rozdziale zatytułowanym: W nowej sytuacji językowej: od kultury zideologizowanej do kultury skomercjalizowanej i reklamy autor kontynuuje wątek związków nazw handlowych z kulturą. Wskazuje na obecność w tego typu onimach procesów o charakterze globalnym (nazwy o rodowodzie anglo-amerykańskim: Copy Shop, Corner Pub, Pink Sport, nazwy francuskie: Madame, L'Image, włoskie: Dolce Vita, Tosca [Siwiec 2012: 106]), procesy perswazyjne (Mój Dom, Moja Mama i Ja, Styl i Ty), gry językowe (Stoń Torbalski, Bosca Szafa, Galeria Przedmiotów Wyjątkowych Qfer).

W rozdziale pt. Nazwy handlowe $i$ różne typy przestrzeni i relacji przestrzennych w obszarze miasta autor dostrzega istotny wpływ przestrzeni miejskiej na tworzenie się nazw handlowych. Osoby, które je nadają, często kierują się lokalizacją obiektu. Tak powstały m.in. nazwy: Przy Operze, Za Rogiem, $\mathrm{Na}$ Złotej. Poza nazwami tworzy się też logotypy, których forma ma wizualnie odpowiadać treści. Zdjęcia wybranych szyldów zawarte w tym rozdziale są poparciem przedstawionej tezy.

Szczegółowa analiza nazw firm została dokonana w kolejnym rozdziale zatytułowanym: $W$ stronę rozróżnień zwiąanych z rodzajem $i$ charakterem obiektów handlowych: o nazwach firm (na przyktadzie Lublina i w szerszym ujęciu). Autor zwraca w nim uwagę na realizowane współcześnie tendencje oraz mechanizmy nazwotwórcze. W zebranym przez siebie materiale odróżnia nazwy własne firm od tych, które nazywa ,innymi identyfikatorami”. Na podstawie zebranych onimów stwierdza, że nazwy powstały w wyniku dwóch typów motywacji językowej: a) motywacji translokacyjnej-jako efekt gotowej formy językowej (użycie nazwy pospolitej jako nazwy własnej), b) motywacji morfologicznej - głównie nazwy mające formę skrótów językowych. Badacz dokonał dogłębnej analizy i zaklasyfikował $28 \%$ przykładów do nazw o motywacji translokacyjnej oraz $72 \%$ do nazw o motywacji morfologicznej.

W rozdziale pt. Polskie modele i typy nazw firm na tle nazewnictwa firm niemieckich i angielskich: nominacje w zakresie ushug dotyczacych eksploatacji samochodów autor podejmuje się systematyzacji onimów pod względem typów nominacji oraz porównania nazw rodzimych z nazwami niemieckimi i angielskimi. Niestety, autor nie uzasadnia, co zadecydowało o wyborze tych języków. Uznaje je tylko za dobry przykład języków z obszaru zachodnioeuropejskiego. Podaje źródła, z których korzystał - w przypadku nazw polskich była to internetowa baza firm www.pkt.pl, o niemieckich firmach czerpał informacje $\mathrm{z}$ różnych baz firm branży samochodowej, a nazwy angielskie pochodzą z internetowej bazy firm Yell.com the UK's local business search engine. 
Wynikiem szczegółowej analizy przeprowadzonej przez Adama Siwca jest klasyfikacja typów nominacji występujących w nazwach polskich:

a) opisowe formuły informujące, złożone z kilku wyrazów pospolitych, np. Mechanika pojazdowa, Sprzedaż hurtowa i detaliczna części samochodowych, blacharstwo;

b) nominacje zawierające leksem auto, np. Auto-Service, Autopunkt, Automechanika;

c) nominacje obejmujące nazwisko właściciela, np. Centrum Koper, Łada-Januszewski, Autoserwis Majewscy;

d) nazwy zawierające imiona, np. U Pawła, Konrad Service, Mati-Alarm;

e) nazwy z motywacją toponimiczną, np. Toyota Bielany, Autogaz-Jelonki, Auto-Białotęka;

f) nazwy w formie skrótowo-złożonej, np. Blach-Lak-Car, Blamech, Got-Car;

g) nazwy, w których całą nazwę lub jej część stanowią wielkie litery, np. $B L S W, B M$ Motors $W, A \& A$ Cars;

h) inne.

Klasyfikacja została uzupełniona tabelą, w której zamieszczono liczbę nazw z podziałem na typy nominacji w Warszawie i Lublinie.

Porównanie typów nominacji nazw polskich $\mathrm{z}$ angielskimi i niemieckimi pozwoliło na uznanie, że istnieją pewne uniwersalne modele w tym zakresie. We wszystkich językach przejawia się dążność do przekazania w nazwie informacji o działalności firmy, rodzaju i przedmiocie usług. Układ typów nazewniczych jest związany ze specjalnością, branżą, ale także warunkami gospodarczymi kraju.

W ostatnim rozdziale pt. Nazwy sklepów i placówek ustugowych w Lublinie omówione zostały szczegółowo nazwy obiektów funkcjonujących w przestrzeni tego miasta, w których odbijają się tendencje charakterystyczne dla przedstawianej kategorii propriów oraz powtarzają się motywy nazewnicze. Materiał z tej części również został wzbogacony zdjęciami szyldów firmowych i sklepowych.

Recenzowana książka jest pracą niezwykle wartościową ze względu na przeprowadzoną w niej przez autora dogłębną analizę takiej kategorii nazw własnych, która odgrywa istotną rolę we współczesnej onimii. W publikacji brak wyraźnego podziału na część teoretyczną i materiałową (część druga ma bowiem de facto charakter teoretyczno-materiałowy), co prawdopodobnie jest konsekwencją uznania przez autora, że w badaniach tego typu konieczne jest ciągłe poszerzanie teorii. Rozważania teoretyczne wplecione są zatem 
pomiędzy analizę zebranych nazw własnych. „Poruszanie się” po monografii ułatwiają rozbudowane tytuły rozdziałów, które dokładnie informują, jakiego problemu dana część dotyczy. Bardzo przydatne są też zdjęcia ilustrujące przykłady oraz tabele systematyzujące dane. Autor - jak już wspomniano - przeprowadził analizę wybranych grup onimów w Krakowie, Poznaniu, Lublinie, Warszawie, Bydgoszczy i Toruniu. Szczegółowo omówił nazwy obiektów handlowych, dokonując ich charakterystyki i klasyfikacji. Nie wyjaśnił jednak motywacji wyboru proprialnej nominacji w tych miastach jako przedmiotu badań ani nie wskazał jasno powodu zestawienia ich z nazwami niemieckimi oraz angielskimi, nie uzasadnił też przeprowadzenia bardziej szczegółowej analizy nazw w Lublinie. Przyczyny tych wszystkich działań poznajemy dopiero w Uwagach końcowych, w których badacz pisze wprost, że zaprezentowane w monografii ,analizy i interpretacje mają charakter otwarty” [Siwiec 2012: 203]. Wymagają zatem dalszych badań - być może także w innych miastach oraz systematyzacji. 